\author{
(1) Fethi Gül, \\ (1) Beliz Bilgili, \\ (1) Mustafa Kemal Arslantaş, \\ (1) Seçil Özcan Ayhan, \\ (1) İsmail Cinel
}

\section{Renal Resistive Index is Unsusceptible to Systemic Hemodynamics in Fluid Responsive Critically III Patients}

\author{
Sıvı Yanıtı Kritik Yoğun Bakım Hastalarında Renal \\ Rezistif Indeks Ölçümü Sistemik Hemodinamik \\ Parametrelerden Etkilenmez
}

Received/Geliş Tarihi : 19.06.2019

Accepted/Kabul Tarihi : 23.09.2019

${ }^{\circ}$ Copyright 2019 by Turkish Society of Intensive Care Turkish Journal of Intensive Care published by Galenos Publishing House.

Fethi Gül, Beliz Bilgili, Mustafa Kemal Arslantaş, Seçil Özcan Ayhan, Ismail Cinel

Marmara University Pendik Training and Research Hospital, Clinic of Anesthesiology and Critical Care, Istanbul, Turkey

Ismail Cinel MD (凶),

Marmara University Pendik Training and Research Hospital, Clinic of Anesthesiology and Critical Care, Istanbul, Turkey

E-mail : cinelismail@yahoo.com

Phone : : +905324129596

ORCID ID : orcid.org/0000-0002-7595-1295
ABSTRACT Objective: The primary goal of fluid resuscitation in critically ill patients is to improve oxygen delivery to ensure adequate organ perfusion. Little evidence is known about renal response to fluids in the acute phase, so renal monitoring after the fluid challenge is fundamental during critical care stay. This study aimed to evaluate changes in the renal resistive index (RRI) and to compare these changes with hemodynamic parameters after fluid challenge in fluid responsive critically ill patients.

Materials and Methods: Thirty patients older than 18 years who underwent sedation and received mechanical ventilation were prospectively studied. Twenty patients were fluid responsive and were included in the study. An increase of cardiac output by $10 \%$ or more after PLR measured by Ultrasonic Cardiac Output Monitor (USCOM) suspected fluid responsiveness. $500 \mathrm{ml}$ of isotonic solution was administered intravenously for 30 minutes. Cardiac output (CO) measurements were performed at 0, 1 and 30 minutes. RRI and mean arterial pressure (MAP) were measured by Doppler ultrasonography at 0 and 30 minutes. Repeated measures ANOVA method was used for statistical analysis and $\mathrm{p}<0.05$ was considered significant.

Results: CO increased significantly after fluid challenge when compared to baseline (from $3.48 \pm 1.14$ to $4.34 \pm 1.43 \mathrm{~L} / \mathrm{min}, \mathrm{p}<0.001)$. MAP increased significantly after fluid administration when compared to baseline $(80 \pm 19$ to $86 \pm 17, p=0.002)$. RRI did not significantly differ from baseline after fluid challenge $(62 \pm 9$ to $60 \pm 10, p=0.11)$. There was a negative correlation between $\mathrm{RRI}$ and MAP at baseline and after fluid challenge.

Conclusion: The effect of hemodynamic changes on renal perfusion after fluid challenge is controversial. In our study, $500 \mathrm{ml}$ of crystalloid treatment for 30 minutes increased MAP and $\mathrm{CO}$, but did not contribute to the improvement of RRI in patients who were fluid responsive. We found that fluid challenge did not improve RRI in the early phase of the fluid resuscitation in fluid responsive critically ill patients and $\mathrm{RRI}$ is unsusceptible to systemic hemodynamic changes during this period.

Keywords: Renal resistive index, macrohemodynamics, renal circulation, fluid responsiveness

ÖZ Amaç: Kritik hastalarda SIVı resüsitasyonunun temel hedefi oksijen sunumunu artırarak organ perfüzyonunun sürdürülmesidir. Yoğun bakımda sıvı tedavisi renal monitorizasyon ilişkisi önemli olup, erken fazda sıvı tedavisine böbreğin yanıtı ile ilişkili literatür bilgisi kısıtıdır. Bu çalışmada sıvı yanıtlı kritik yoğun bakım hastalarında sıvı replasmanından sonra renal rezistif indeks(RRI) değişimi ve bu değişimin hemodinamik parametrelerle olan ilişkinin değerlendirilmesi amaçlandı.

Gereç ve Yöntem: Mekanik ventilasyon desteği altında 18 yaşından büyük, sedatize ve sıvı yanıtı 20 hasta prospektif olarak çalışmaya dahil edildi. Pasif bacak kaldırma testi sonrası noninvaziv kardiyak monitörizasyon (USCOM) cihazında kardiyak outputda (CO) \%10 ve daha fazla artış göstererenler sıvı yanıtlı olarak kabul edildi. Bu hastalara 30 dakika içersinde $500 \mathrm{ml}$ izotonik solüsyonu intravenöz verildi. CO ölçümleri 0, 1 ve 30. dakikalarda yapıldı. RRI ve ortalama arteryal basınç $(\mathrm{OAB})$ değerlerinin ölçümleri 0 ve 30. dakikalarda alındı. İstatiksel analiz için tekrarlayan ANOVA yöntemi uygulandı ve $p<0.05$ anlamlı kabul edildi. 
Bulgular: Sıvı yüklemesinden sonra CO artışı bazale göre anlamlı şekilde artış gösterdi $(3.48 \pm 1.14$ 'den $4.34 \pm 1.43$ L/dakikaya , $P<0.001)$. OAB sıvı tedavisinden sonra bazal değerlere göre anlamlı şekilde artış gösterdi ( $80 \pm 19$ 'den $86 \pm 17$ 'e, $P=0.002)$. Sıvı replasmanından sonra RRI'de anlamlı değişiklik saptanmadı(62 $\pm 9^{\prime}$ den $60 \pm 10^{\prime}$ e, $\left.P=0.11\right)$. OAB ve RRI arasında hem başlangıçta hem de sıvı yüklemesinden sonra negatif korelasyon saptandı.

Sonuç: Sıvı yüklemesinden sonra sistemik hemodinamik değişikliklerin renal perfüzyon üzerindeki etkisi tartışmalıdır. Çalışmamızda sıvı yanıtı hasta grubunda 30 dakikada $500 \mathrm{ml}$ kristaloid yüklemesinden sonra OAB ve CO artarken, RRI'da anlamlı değişiklik saptanmadı. Bu çalışmada sıvı yanıtı kritik yoğun bakım hastalarında sıvı resüsitasyonun erken fazında RRI'de anlamlı değişiklik olmadığı ve RRI'nın sistemik hemodinamik değişikliklerden etkilenmediği saptandı.

Anahtar Kelimeler: Renal rezistif indeks, makrohemodinamikler, renal sirkülasyon, sıvı yanıtlıı̆̆ı

\section{Introduction}

Intravascular fluid administration is a crucial point for hemodynamic optimization during critical care practice for favorable outcomes. The main goal for the fluid challenge is to enable adequate intravascular volume for improved oxygen delivery or maintaining organ perfusion by increasing stroke volume (1). Fluid administration should be in balance because minor volume loading may cause deleterious effects such as lung edema, hypertension, organ congestion, and decreased survival. On the other hand, volume depletion can cause hypotension and shock, which carries a progressive risk for end-organ underperfusion, such as acute kidney injury (AKI) (2).

Proper fluid loading is a first-line therapy to improve oxygen delivery to ensure organ perfusion. Evaluating the current state of the patient's intravascular volume is also critical for maintaining volume expansion, which can be measured by invasive and non-invasive monitoring modalities. In clinical practice, physiological variables such as blood pressure, urine output, and laboratory parameters are used to assess the patient's intravascular volume state. On the other hand, some methods addressed to predict intravascular volume status and patient's response to fluid loading (3). Static cardiac filling pressures are poor predictors whereas dynamic parameters such as stroke volume variation (SVV) and pulse pressure variation (PPV) have shown to be capable of guiding fluid therapy in various patient population (4). In addition to these methods, passive leg raising (PLR) has been proposed a simple reliable clinical test which provides a fast and accurate way for both spontaneously breathing and mechanically ventilated patients to augment intravascular volume (5).

The ultrasonic cardiac output monitor (USCOM) is a non-invasive, user-friendly and based on continuous-wave Doppler monitor which obtain reliable CO measurements. Clinical studies have shown a good correlation between USCOM based and bolus thermodilution to that of other minimally invasive cardiac output measurements (6)

Little evidence is known about renal monitoring after fluid, so identify appropriate patients in whom renal hemodynamics improve in response to fluids is a fundamental treatment option during critical care stay (7). Fluid resuscitation and maintaining adequate blood flow, prevention of systemic hypotension and increment cardiac output are the first-line therapies to restore renal circulation to prevent AKI.

Renal resistive index (RRI), measured by renal interlobar artery Doppler ultrasonography, is a successful non-invasive bedside monitoring modality which directly reveals and quantifies modifications in renal vascular resistance with high diagnostic accuracy in critically ill patients following various therapeutic interventions.

Doppler RRI is a real-time bedside easily performed dynamic imaging technique for repeated assessments of the renal circulation at the bedside in ICU with several advantages such as rapidity, feasibility, portability, and simplicity (8). It helps to clarify the endpoint to hemodynamic treatment and particularly important to predict severity of $\operatorname{AKI}(9,10,11)$. RRI values are usually obtained by translumbar or transabdominal Doppler approach but measurements can also accessible with the transesophageal echocardiography (12).

The aim of this study was to evaluate changes in RRI after fluid challenge in fluid responsive critically ill patients and to compare these changes with the hemodynamic parameters.

\section{Materials and Methods}

\section{Patients}

This prospective study was performed over a period of 12 months in patients admitted to the Anesthesiology and Intensive Care Unit (AICU) of the Marmara University Training and Research Hospital. Intubated, sedated, mechanically ventilated patients without spontaneous breathing who had a fluid challenge were included. The present study was approved by the Ethics Committee of Marmara University. 
The exclusion criteria were as follows: inability to defer fluid challenge, nonsinus cardiac rhythm that affected renal resistive index, pregnancy, heart failure, acute/chronic renal failure or renal artery disease (unilateral kidney, renal stone disease, renal artery stenosis) and a contraindication to PLR.

\section{RRI and Cardiac Output (CO) Measurements}

All sonographic measurements were performed using Philips EPIQ 7 ultrasound system (Philips Healthcare, Inc., Andover, MA, USA) by trained intensivist who certified in ultrasonography.

Renal Doppler was performed on the interlobar arteries using a convex probe. Renal vasculature was identified using color Doppler, and then the arterial waveforms were obtained by pulsed-wave Doppler in the interlobar renal artery (Figure 1). RI at the interlobular or arcuate artery near the border of the central echo complex was measured three times in the upper, middle, and lower portions of the kidney. In each patient, the renal RI was calculated with the following formula: $(\mathrm{RRI}=$ [peak systolic velocity - end diastolic velocity] / peak systolic velocity). Three measurements were performed and the mean value of three measurements at each kidney calculated (12).

Non-invasive Ultrasonic Cardiac Output Monitor (USCOM; USCOM Ltd., Sydney, Australia, 2005) was used to measure cardiac output transcutaneously via a probe applied to the suprasternal notch at baseline, after PLR, and after fluid challenge.

\section{Hemodynamic measurements, Passive Leg Raising، and Fluid Challenge}

At each step of the study systolic blood pressure (SAP), mean arterial pressure (MAP), diastolic blood pressure

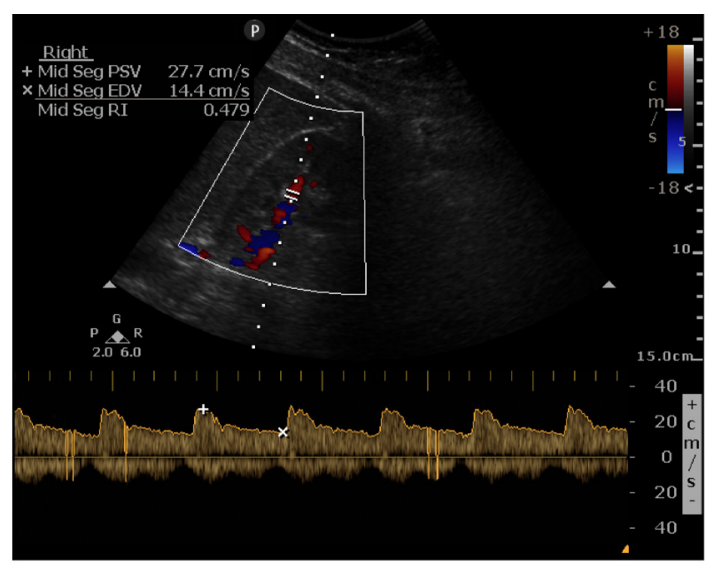

Figure 1. Example of color-flow Doppler imaging of pulsed-wave Doppler obtained by translumbar USG in the interlobar renal artery
(DAP), heart rate (HR) and CO parameters were conducted by a critical care specialist. All data were recorded using an electronic system. Cardiac output during passive leg raising was measured by using USCOM. A greater than 10\% increase in cardiac output would predict volume responsiveness and an indication for a $500-\mathrm{mL}$ fluid bolus (13).

Baseline measurements were made when the patients were placed in a semi-recumbent position with the head elevated at 45 degrees. In the second stage, the patients were placed in a supine position with the legs straight and elevated at 45 degrees for one minute, and immediately second measurements were noted. After this, patients were taken to the baseline position and in whom CO increased by more than than $10 \%$ at the second stage was accepted as volume responders. Lastly, in volume responder patients who were included in the study, a $500 \mathrm{~mL}$ isotonic bolus infusion in 30 minutes were given and the measurements were recorded immediately after the completion of the infusion.

Patients in whom volume expansion increased $\mathrm{CO}$ by more than $10 \%$ were defined as "volume responders" and the remaining ones as "volume non-responders." This cutoff was justified by the fact that the least significant change (LSC) of CO measured by using USCOM is $1 \%$ when three measurements are averaged.

\section{Statistical analysis}

Power analysis (G*power: Faul and Erfelder 1992) suggested that a minimum of 19 patients would be needed for a $\beta=0.1$, effect size $=0,7$ and $\alpha=0.05$. To compensate for potential dropouts, we enrolled 20 patients in this study. All data tested for normally distributed (Kolmogorov-Smirnov test) and are expressed as mean \pm standard deviation (SD) or as median [25-75\% interquartile range, IQR], as appropriate. Pairwise comparisons of values between different study times were performed by paired Student's t test or Wilcoxon test, as appropriate. Correlations were tested by the Pearson method. The level of statistical significance was set at $\mathrm{P}<$ 0.05 . Statistical analysis was performed using MedCalc 16 (Mariakerke, Belgium)

\section{Results}

Thirty intubated patients ( 26 men and 4 women; mean [ \pm SD] age, 50 years) were studied. 20 patients were fluid responsive and included to study. The demographic characteristics of the patients are presented in Table 1. 


\section{The Effects of Volume Expansion on $\mathrm{CO}$ and RRI}

Data at baseline and after fluid resuscitation are shown in Table 2. The RRI was comparable before and after the fluid challenge. In contrast, after volume replacement, a significant increase was observed in $\mathrm{CO}$ and MAP. A significant HR decrease was recorded at the 30th minute.

There was a negative correlation with a Pearson correlation coefficient 0.487 between RRI and MAP at the baseline. We also found a significant negative correlation with a Pearson correlation coefficient 0.579 between RRI and MAP after fluid challenge (Figure 2).

Specifically, CO (from $3.48 \pm 1.14$ to $4.34 \pm 1.43 \mathrm{~L} / \mathrm{min}$, $\mathrm{P}<0.001$ ) (Figure 3 ) and MAP $(80 \pm 19$ to $86 \pm 17, P=0.002)$
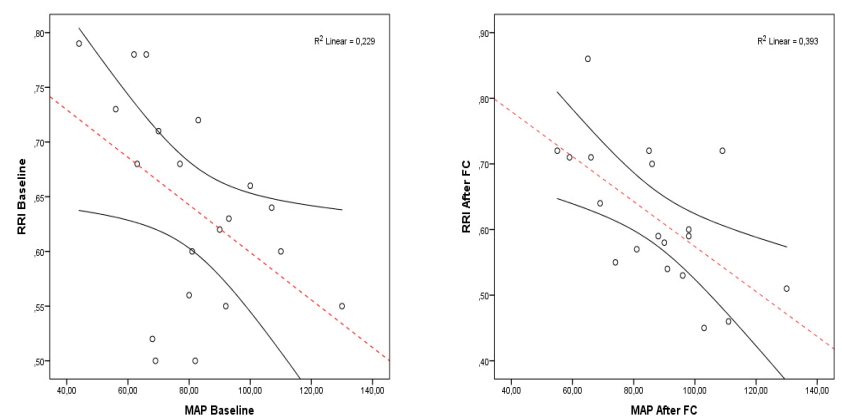

Figure 2. From the scatter plot, we can see that RRI tends to decrease as MAP increases. There is a linear relationship in the opposite direction

\begin{tabular}{|l|l|}
\hline \multicolumn{2}{|l|}{ Table 1. Demographic data of patients $(\mathbf{n}=\mathbf{2 0})$} \\
\hline Patient characteristic & \\
\hline Age (years)(range) & $50(18-79)$ \\
\hline Gender (male/female) & $19 / 1$ \\
\hline BMI (Mean $\pm S D)$ & $19.55 \pm 10.73$ \\
\hline APACHE II (Mean \pm SD) & $15.42 \pm 5.10$ \\
\hline SOFA (Mean $\pm S D)$ & $7.12 \pm 2.83$ \\
\hline $\begin{array}{l}\text { BMI: Body Mass Index, APACHE: Acute Physiology and Chronic Health Evaluation, } \\
\text { SOFA: Sequential Organ Failure Assessment }\end{array}$ \\
\hline
\end{tabular}

(Figure 4) increased significantly after fluid challenge compared to baseline. HR significantly decreased from the baseline after fluid resuscitation $(111 \pm 21$ to $106 \pm 21 \mathrm{~L} /$ $\min , p=0.016)$. We observed a non-significant decrease in $\mathrm{RRI}$ after a fluid challenge from the baseline $(0.62 \pm 0.9 \mathrm{vs}$ $0.60 \pm 0.1, P=0.11$ ) (Figure 5) .

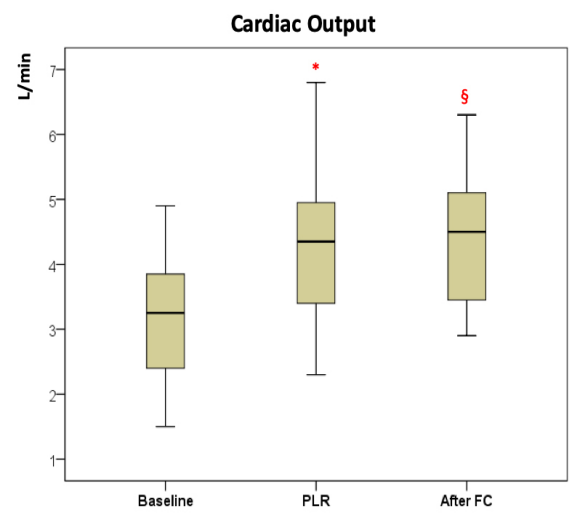

Figure 3. Cardiac output at baseline, during passive leg raising(PLR) and after fluid challenge(FC) which was measured by USCOM

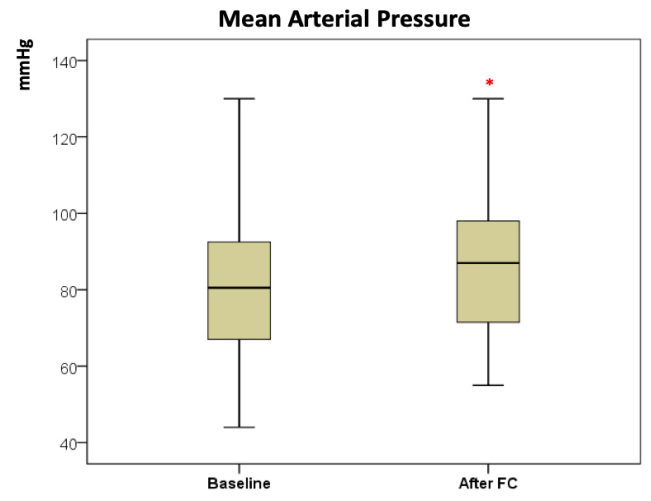

Figure 4. Mean arterial pressure had increased statistically meaningfull after fluid challenge (FC) to compare baseline measurements

\begin{tabular}{|c|c|c|c|c|c|}
\hline \multirow{2}{*}{ Parameter } & \multicolumn{2}{|c|}{ Baseline } & \multicolumn{2}{|c|}{ After FC } & \multirow{2}{*}{$P$} \\
\hline & Mean & Std. Deviation & Mean & Std. Deviation & \\
\hline RRI & 0.62 & 0.09 & 0.60 & 0.10 & 0.114 \\
\hline HR (bpm) & 111.11 & 21.48 & 106.81 & 21.59 & 0.016 \\
\hline MAP(mmHg) & 80.96 & 19.04 & 86.44 & 17.50 & 0.002 \\
\hline $\mathrm{CO}(\mathrm{L} / \mathrm{min})$ & 3.48 & 1.14 & 4.34 & 1.43 & 0.001 \\
\hline
\end{tabular}




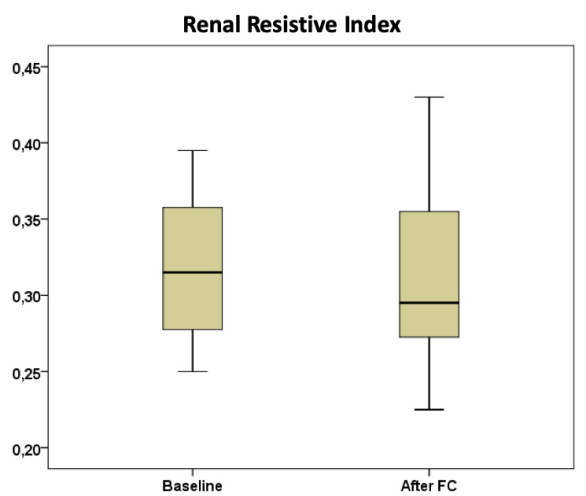

Figure 5. Renal Resistive Index (RRI) at the baseline and after fluid challenge( $F C$ )

\section{Discussion}

In this study, our primary objective was to investigate the changes in RRI after the fluid challenge in patients who were fluid responsive and secondly evaluate the relationship between RRI and MAP. Our results demonstrated that 500 $\mathrm{ml}$ of crystalloid treatment for 30 minutes had contributed a significant increment in MAP without a change RRI in the early phase of resuscitation in intravascular volume-depleted patients. Although fluid challenge did not improve RRI, a significant negative correlation was observed between MAP and RRI indicating that macrocirculation may have an influence on renal circulation.

Fluid resuscitation is the standard treatment for hypovolemia and vital for all organs. It is critical to predict fluid responsiveness in volume-depleted patient and improve hemodynamic status for end-organ perfusion. Now, it is well known that passive leg raising (PLR) is a reversible dynamic test which is a maneuver that mimics rapid volume expansion. This test can be used in conditions where respiratory variations of stroke volume have limitations, such as arrhythmias, low tidal volume ventilation, low lung compliance and spontaneously breathing patients (5). PLR results physiologically pump of approximately 250-300 $\mathrm{mL}$ venous blood from the lower extremities to the heart which increases the cardiac preload so an accurate test for increasing $\mathrm{CO}$ in patients who will benefit from fluid resuscitation (14). PLR has been used as a simple bedside effective method for predicting fluid responsiveness both in critically ill adult and child patients with the cutoff value of an increase in cardiac output of $\geq 10 \%$. It is a maneuver that may provide an accurate alternative to guide fluid resuscitation in hypovolemic critically ill patients (15). We measured CO by USCOM, a non-invasive cardiac output monitoring in situations where other more invasive monitors may not be available or applicable and which has an acceptable correlation to other invasive techniques $(16,17)$.

$\mathrm{RRI}$ has been used for years in a variety of clinical settings, especially to differentiate acute and chronic obstructive renal disease. In addition to this, in recent years accumulating evidence has shown RRI may provide useful information about changes in intrarenal perfusion in critically ill patients. Results of some studies propose that RRI can differentiate prerenal from intrinsic AKI $(18,19)$. In preliminary studies, it was suggested that doppler based RRI measurements might helpfull predict delayed and the reversibility of AKI with high sensitivity and specificity in critically ill patients $(20,21)$. RRI > 0.72 allows earlier detection of AKI before other biochemical parameters increase such as creatinine, so careful fluid management and hemodynamic adjustments with avoiding the use of nephrotoxic medication is possible (18). In our study, even though mean baseline RRI (0.62) was in the normal ranges according to literature and even a nonsignificant slight decrease was observed in RRI after fluid challenge, a negative correlation between RRI and MAP was shown.

Accumulating evidence about the influence of systemic hemodynamic changes on the renal resistive index is controversial. In a study, it was reported that RRI is inversely correlated with MAP in septic patients without AKI, but a positive correlation was observed in septic patients with AKI. The main finding of this study was that renal Doppler ultrasonography was not a reliable method to predict renal circulatory response to significant changes in systemic hemodynamics (23). Contrary to this study, some reports suggested that $R R I$ is a relevant endpoint in the hemodynamic management of septic shock. It was shown that RRI significantly decreased when mean arterial pressure was increased with a significant increasing urinary output (10). In our study, we did not retrieve any correlation between fluid challenge and RRI. In addition to this, a negative correlation was observed between RRI and the MAP, which had a tendency to increase significantly after volume replacement. Our data emphasize the relative dissociation of systemic and intrarenal hemodynamics. More importantly, the insignificant $\mathrm{RRI}$ change according to the increment in MAP suggests that regional renal circulation doesn't depend on systemic hemodynamic factors in the early phase of resuscitation in intravascular volume-depleted patients. 


\section{Limitations}

The present study has some limitations. First, we enrolled a mixed population of critically ill patients, which may be a misleading factor. Secondly, RRI measurements can be affected by several additional factors, including interstitial edema, oxygen, and carbon dioxide levels, which we didn't taken into account.

\section{Conclusion}

Many studies continue to search for new reliable parameters to guide tissue perfusion. Timely, accurate, and reproducible determination methods are crucial to the adequate management of critically ill patients. In recent years, clinical care shift towards minimally invasive monitoring modalities. Clinical studies had mainly focused on predicting the effect of volume expansion on end organs. We investigated the changes in renal circulation after fluid challenge, yet the renal effects of fluid resuscitation are not easily assessed. Indeed, systemic hemodynamic factors may influence renal regional circulation, renal resistive index is unsusceptible to systemic hemodynamic changes in the early phase of the fluid resuscitation in fluid responsive critically ill patients.

\section{Conflict of Interest}

Authors declare no conflict of interest. 


\section{References}

1. Gernot $M$, Achim WS, Christoph $M$, Joerg A, Michael B, Irmela G, et al. Intravascular volume therapy in adults. Guidelines from the Association of the Scientific Medical Societies in Germany. Eur J Anaesthesiol 2016; 33:488-521

2. Kalantari K, Chang JN, Ronco C, Rosner $\mathrm{MH}$. Assessment of intravascular volume status and volume responsiveness in critically ill patients. Kidney Int. 2013 ;83(6):1017-28

3. Osman D, Ridel C, Ray P, Monnet $X$, Anguel $N$, et al. Cardiac filling pressures are not appropriate to predict hemodynamic response to volume challenge. Crit Care Med 2007;35: 64-8.

4. De Backer D, Taccone FS, Holsten $R$, Ibrahimi F, Vincent JL. Influence of respiratory rate on stroke volume variation in mechanically ventilated patients. Anesthesiology 2009; 110: 1092-7.

5. Monnet X, Rienzo M, Osman D, Anguel $\mathrm{N}$, Richard C, Pinsky MR, et al. Passive leg raising predicts fluid responsiveness in the critically ill. Crit Care Med 2006; 34: 1402-7.

6. Chong SW, Peyton PJ . A meta-analysis of the accuracy and precision of the ultrasonic cardiac output monitor (USCOM). Anaesthesia 2012, 67, 12661271

7. Mouhamed DM, Sabino S, David F, Pierre P, Alexandre B, Fabio ST, et al. Effects of fluid administration on renal perfusion in critically ill patients. Crit Care 2015; 19:250

8. Schnell D, Darmon M. Bedside Doppler ultrasound for the assessment of renal perfusion in the ICU: advantages and limitations of the available techniques. Crit Ultrasound J. 2015;7(1):24.

9. Haitsma Mulier JLG, Rozemeijer S, Röttgering JG, Spoelstra-de Man AME, Elbers PWG, Tuinman PR, et al.
Renal resistive index as an early predictor and discriminator of acute kidney injury in critically ill patients; A prospective observational cohort study. PLoS One. $2018 ; 11 ; 13(6)$ : 0197967.

10. Deruddre $\mathrm{S}$, Cheisson G, Mazoit JX, Vicaut E, Benhamou D, Duranteau J. Renal arterial resistance in septic shock: effects of increasing mean arterial pressure with norepinephrine on the renal resistive index assessed with Doppler ultrasonography. Intensive Care Med. 2007;33(9):1557-62.

11. Kuznetsova $T$, Cauwenberghs $N$, Knez J, Thijs L, Liu YP, Gu YM, et al: Doppler indexes of left ventricular systolic and diastolic flow and central pulse pressure in relation to renal resistive index. Am J Hypertens 2015; 28: 535-545.

12. Kararmaz A, Arslantas MK, Cinel I. Renal Resistive Index Measurement by Transesophageal Echocardiography: Comparison With Translumbar Ultrasonography and Relation to Acute Kidney Injury. J Cardiothorac Vasc Anesth 2015; 29(4) : 875-80

13. Cecconi M, De Backer $D$, Antonelli M, Beale R, Bakker J, Hofer C, et al. Consensus on circulatory shock and hemodynamic monitoring. Task force of the European Society of Intensive Care Medicine. Intensive Care Med 2014; 40:1795-815.

14. Monnet $X$, Rienzo M, Osman D, Anguel $\mathrm{N}$, Richard C, Pinksy MR, et al. Passive leg raising predicts fluid responsiveness in the critically ill. Crit Care Med. 2006; 34:1402-7.

15. Monnet $X$, Teboul JL. Passive leg raising. Intensive Care Med. 2008; 34:659-63.

16. Horster S, Stemmler HJI, Strecker $\mathrm{N}$, Brettner F, Hausmann A, Cnossen J, et al. Cardiac Output Measurements in Septic Patients: Comparing the Accuracy of USCOM to PiCCO. Crit Care Res Pract. 2012;2012:270631.

17. van Lelyveld-Haas LE, van Zanten
AR, Borm GF, Tjan DH. Clinical validation of the non-invasive cardiac output monitor USCOM-1A in critically ill patients. Eur J Anaesthesiol. 2008;25(11):917-24.

18. Izumi $M$, Sugiura $T$, Nakamura $H$, Nagatoya K, Imai E, Hori M. Differential diagnosis of prerenal azotemia from acute tubular necrosis and prediction of recovery by Doppler ultrasound. Am J Kidney Dis 2000; 35:713-9

19. Stevens PE, Gwyther SJ, Hanson ME, Boultbee JE, Kox WJ, Phillips ME. Noninvasive monitoring of renal blood flow characteristics during acute renal failure in man. Intensive Care Med 1990; 16:153-8

20. Bossard G, Bourgoin P, Corbeau JJ, Huntzinger J, Beydon L. Early detection of postoperative acute kidney injury by Doppler renal resistive index in cardiac surgery with cardiopulmonary bypass. $\mathrm{Br}$ J Anaesth 2011; 107:891-8.

21. Michael $D$, Fre'de'rique $S$, Frederic $V$, Aissam L, Benoît S, Christian BB, et al. Diagnostic accuracy of Doppler renal resistive index for reversibility of acute kidney injury in critically ill patients. Intensive Care Med 2011; 37:68-76

22. Marty P, Szatjnic S, Ferre F, Conil JM, Mayeur N, Fourcade O, et al. Doppler renal resistive index for early detection of acute kidney injury after major orthopaedic surgery. A prospective observational study. Eur J Anaesthesiol 2015; 32:37-43

23. Dewitte A, Coquin J, Meyssignac $B$, Joannès-Boyau O, Fleureau $C$, Roze $\mathrm{H}$, et al. Doppler resistive index to reflect regulation of renal vascular tone during sepsis and acute kidney injury. Crit Care. 2012; 12;16(5): 